\title{
Long-Term Delayed Vascularization of Human Neural Transplants to the Rat Brain
}

\author{
Christian Geny, ${ }^{1}$ Souad Naimi-Sadaoui, ${ }^{1,4}$ Roland Jeny, ${ }^{2}$ Abd el Majid Belkadi,, ${ }^{1}$ Sharon L. Juliano, ${ }^{3}$ and Marc \\ Peschanski ${ }^{1}$ \\ 'INSERM CJF 91-02, Neuroplasticité et Greffes Intracérébrales, Faculté de Médecine, 94010 Créteil, France, ${ }^{2 H o ̂ p i t a l ~}$ \\ Esquirol, 94 Saint-Maurice, France, ${ }^{3}$ Department of Anatomy, USUHS, Bethesda, Maryland 20814, and ${ }^{4}$ Laboratoire de \\ neurosciences, Département de Biologie, Faculté des Sciences Semlalia-Marrakech, Morocco
}

\begin{abstract}
Human neural transplants are being developed to treat Parkinson's disease. Previous characterization of human transplants focused on neuronal development, while little is known of the interaction between the transplant and its environment, among which blood is of prime importance. We evaluated here the formation of blood vessels in human neural xenografts placed into the brain of rats immunosuppressed with cyclosporin A. Using capillary wall markers, we found that human transplants remain virtually nonvascularized for more than 1 month. Angiogenesis takes place very slowly and the density of blood vessels is still quite poor after 3 months, the fine structure of these capillaries, when they form, is apparently normal. Functional studies indicate that the vascular network formed in the transplant allows blood circulation and exhibits a working barrier to macromolecules. Glucose uptake and consumption and cytochrome oxidase activity are almost undetectable up to 3 months after grafting.
\end{abstract}

These results demonstrate that vascularization is much delayed in human xenografts into the rat brain. This delay is likely to be dependent on the maturation of the transplanted tissue. A dedifferentiation of human endothelial cells cotransplanted with neural cells occurs since histochemical and immunocytochemical markers revealing endothelial cells in the human fetus are not present up to 1 month in the transplant. The origin of this phenomenon is a matter of speculation. How neural cells survive and mature in such conditions are issues of prime interest for the future of human neural grafting.

[Key words: xenograft, neural transplant, brain metabolism, Parkinson, human fetus, development, angiogenesis]

Human neural transplants have recently been developed to treat Parkinson's disease (Lindvall et al., 1990; Freed et al., 1992; Spencer et al., 1992; Widner et al., 1992; Peschanski et al., in press) and are being considered for use in Huntington's disease.

\footnotetext{
Received Jan. 26, 1994; revised May 20, 1994; accepted June 2, 1994.

Wc thank Dr. Brigitte Onteniente for review of the manuscript, Mrs. Veronique Poli for skillful secretarial help, Dr. Y. Laperche for providing the GGT antibody, and Sandoz labs for cyclosporin A. This work was supported by ANRS, Association Française contre les Myopathies, Assistance publique (CRC 91-1401), INSERM (C.G. and réseau) and a fellowship from the Association Huntington de France (S.N.-S.)

Correspondence should be addressed to Dr. Marc Peschanski, INSFRM CJF 91-02, Faculté de Médecine, 8 Rue du Général Sarrail, 94010 Créteil, France.

Copyright (C) 1994 Society for Neuroscience $0270-6474 / 94 / 147553-10 \$ 05.00 / 0$
}

Clinical application is based upon a wealth of experimental data (Björklund et al., 1987; Freed, 1991) including studies specifically exploring the development of human neural cells transplanted into the brain of adult rats (Brundin et al., 1986, 1988; Strömberg et al., 1986; Wictorin and Björklund, 1992). These studies have concentrated on the morphology of neurons of interest (e.g., mesencephalic dopaminergic neurons). In contrast, little attention has been given to the glial and vascular environment in which transplanted human neurons develop. It has been demonstrated that the blood vessels found in rat or mouse allografts are of host and donor origin (see references and discussion in Rosenstein, 1987; Dusart et al., 1989; Broadwell et al., 1991). Results obtained in these rodent models can, however, be only partly informative regarding survival of human transplants because the rate of maturation of transplanted cells is much longer for human tissue than for corresponding rodent tissue (Brundin et al., 1986). While developing rat neurons may mature over a period of a few weeks after transplantation into adult brain, human neurons take several months to develop. Transplanted neurons, therefore, must survive for long periods of time in an environment that is composed partly of cotransplanted fetal glial and endothelial cells, but also consists of adult host-derived cells and substances. To define the specific developmental characteristics in human transplants, we began to study glial and vascular elements of human xenografts into the brains of immunosuppressed adult rats. The present article deals with the establishment of the vascular network in this model, from an anatomical and a functional point of view.

In the process of transplanting fetal neurons into an adult brain, the blood is one of the major differences in the environment of the transplanted cells, because it is entirely of host origin. The transplanted cells are dependent on host circulation for everything normally provided by blood, including oxygen and metabolic compounds. Interaction between fetal and host endothelial cells is therefore of major importance for the establishment of a functional vascularization. Fetal neural allografts to the adult rat brain are first avascular (Broadwell et al., 1987, 1990; Dusart et al., 1989), leading to an abnormal situation for cells that are normally vascularized in the fetus. Circulation appcars after more than a wcck in a vascular network comparable in density to that of the host. It is not yet understood how the vascular network develops in a human neural graft.

The goal of the present study was to evaluate the vascularization of human transplants using human xenografts in the immunosuppressed rat brain. We analyzed the vascular network using various anatomical and functional markers up to 3 months 
after grafting. Our results indicate that fetal cells develop for more than a month in the absence of a normal vascular network and, for at least 2 additional months, in a poorly vascularized environment. This development pattern is associated with very low levels of oxidative metabolism and glucose uptake in the tissue.

\section{Materials and Methods}

Transplantation procedure. Spinal and brainstem tissue was taken from human fetuses ( $6-8$ weeks gestation) obtained by routine suction abortion (Jeny et al., 1993). According to a protocol accepted by the French National Ethical Committee, fetuses were aspirated under ultrasound guidance into a canula of $12 \mathrm{~mm}$ in diameter. The CNS was freed from the meninges and the brainstem and upper spinal cord, between the cervicothoracic junction and the emergence of cerebellar primordia, wcre disscetcd out. In two cases, intact fetal pieces were used to ascertain the presence of blood vessels. Small blocks of fetal tissue were soaked in a phosphate-buffered solution $(0.1 \mathrm{~m}, \mathrm{pH} 7.4)$ containing $4 \%$ paraformaldehyde for $4 \mathrm{hr}$ then in a phosphate-buffered solution containing $30 \%$ sucrose until they sunk. Sections cut on a cryostat ( $32 \mu \mathrm{m}$ thickness) were treated for the histochemical detection of alkaline phosphatase using the protocol described below. In the other cases, fetal tissue was cut in small cubes $\left(<1 \mathrm{~mm}^{3}\right)$ and dissociated first with trypsin $(0.1 \%$, $20 \mathrm{~min}$ at $37^{\circ} \mathrm{C}+$ DNase, $0.05 \%$ ) and then mechanically by trituration with fire-polished Pasteur pipettes in $200-400 \mu$ l of Hanks' balanced salt solution containing $0.05 \%$ DNase. Final cell concentration was made $40,000-60,000$ cells per microliter. Survival rate, as defined by the acridine orange-ethidium bromide technique was always above $80 \%$ and most often around $95 \%$. From 8 to $10 \mu \mathrm{l}$ of this suspension was stercotactically injected.

Thirty-five adult female Sprague-Dawley rats (200-250 gm) anesthetized with chloral hydrate $(400 \mathrm{mg} / \mathrm{kg})$ were lesioned $1-3$ weeks before transplantation by stereotactic injection of kainic acid $(0.15 \mu \mathrm{l}, 0.5 \%$ aqueous solution over $15 \mathrm{~min}$ ) into the right thalamus (Peschanski and Isacson, 1988). Rats were reanesthetized for stereotactic transplantation of human tissue into the same area. Rats were immunosuppressed with $10 \mathrm{mg} / \mathrm{kg}$ cyclosporin A (generous gift Sandoz labs) daily from the day before transplantation until the day of sacrifice, which was carried out 1,2 , or 3 months after grafting.

Histological procedures. Rats were sacrificed by an overdose of pentobarbital. They were perfused transcardially with warm heparinized saline followed by cold phosphate-buffered saline containing 4\% paraformaldehyde for light microscopy (LM), $2 \%$ paraformaldehyde and $2 \%$ glutaraldchydc for clcctron microscopy (EM). The block of brain tissue containing the transplant was soaked in the same fixative for $4 \mathrm{hr}$ and then cryoprotected (LM) in $30 \%$ sucrose phosphate buffer until it sunk, or kept in cold buffer (EM). For LM, sections were cut at $32 \mu \mathrm{m}$ thickness on a cryostat and allowed to dry on gelatinized slides. For EM a block containing the transplant was cut (50 $\mu \mathrm{m}$ thickness) on a vibratome (Oxford Inst.). Sections were embedded flat in Epon after osmication $\left(\mathrm{OsO}_{4}, 1 \%, 1 \mathrm{hr}\right)$ and dehydration in progressive alcohols. Semithin (1 $\mu \mathrm{m})$ and ultrathin sections were cut on an ultramicrotome and stained with toluidine blue or uranyl acetate and lead citrate, respectively.

A few sections from each brain were Nissl stained with cresyl violet, to allow identification of surviving transplants (see Results) in 23 rats, of which 16 were prepared for histochemistry and immunocytochemistry at the light microscopic level, three for electron microscopy, and two sustained either 2-deoxyglucose or HRP injection before sacrifice. For LM, adjacent sections were treated for histochemistry for alkaline phosphatase (Sigma), RCA-1 lectin binding (Sigma), cytochrome oxidase (Sigma) and for immunocytochemistry using antibodies raised against rat $\gamma$-glutamyl transpeptidase (GGT; generous gift Dr Yannick Laperche), mouse laminin (Sigma), or human leucocyte antigen class 1 (HLA-1, Dako). Histochemistry for (1) alkaline phosphatase, (2) RCA-1 lectin binding, and (3) cytochrome oxidase was carried out by treating sections, respectively, (1) with naphthol AS phosphate $(0.02 \%)+$ dimethyl formamide ( $2 \%)$ and fast red TR salt $(0.1 \%)$ in Tris-buffered saline ( $0.1 \mathrm{M}, 2 \mathrm{hr}$, in the dark); (2) with RCA-1 lectin (10\%) in phosphate buffer saline $(0.1 \mathrm{M}$, overnight), and sections were then incubated with diaminobenzidine $\left(0.025 \%\right.$ in Tris $0.05 \mathrm{M}$ containing $0.01 \% \mathrm{H}_{2} \mathrm{O}_{2}, 15$ $\mathrm{min}$ ); or (3) with cytochrome c (type III, $44.4 \mathrm{mg} / 100 \mathrm{ml}$ ), diaminobenzidine $(55 \mathrm{mg} / 100 \mathrm{ml})$, and saccharose $(4.4 \mathrm{gm} / 100 \mathrm{ml})$ in phosphatc buffer $(0.1 \mathrm{M}, 3 \mathrm{hr})$, and sections were then washed, dehydrated, and mounted.
Immunocytochemistry for GGT, laminin, and HLA-1 was carried out using the $\mathrm{ABC}$ technique with Vectastain kits (Vector labs) in normal goat serum $(1 \%)$ containing $0.3 \%$ Triton-X. Sections were incubated overnight with antibodies raised in rabbit against GGT (1:500) or laminin (1:100), in mouse against HLA-1 $(1: 100)$, and then for $1 \mathrm{hr}$ successively with goat anti-rabbit or horse anti-mouse (rat-adsorbed) biotinylated antibodies (1:200) and the avidin-biotin-HRP complex (1: $300)$. Sections were incubated with diaminobenzidine $(0.025 \%$ in Tris buffer $0.05 \mathrm{M}$ ) and $\mathrm{H}_{2} \mathrm{O}_{2}(0.015 \%)$ for $20 \mathrm{~min}$, dehydrated, and mounted.

Functional analysis. Rats were anesthetized with chloral hydrate $(400$ $\mathrm{mg} / \mathrm{kg}$ ) and the jugular vein catheterized. ${ }^{14} \mathrm{C}-2$-deoxyglucose (2-DG; Amersham; $10 \mu \mathrm{Ci}$ ) or horseradish peroxidase (HRP; Sigma; $12.5 \mathrm{mg}$ ) was injected and allowed to circulate for $45 \mathrm{~min}$. Rats were sacrificed by an overdose of pentobarbital and perfused transcardially with warm heparinized saline followed by cold phosphate-buffered saline containing either $1 \%$ paraformaldehyde (2-DG) or a mixture of $2 \%$ paraformaldehyde and $2 \%$ glutaraldehyde (HRP). The block of brain tissue containing the HRP-labeled transplant was cryoprotected in $30 \%$ sucrose phosphate buffer until it sunk.

Sections were cut at $16 \mu \mathrm{m}$ (2-DG) or $48 \mu \mathrm{m}$ (HRP) in a cryostat and either allowed to dry on gelatinized slides (2-DG) or kept floating (HRP). 2-DG containing sections were apposed for 1 week onto autoradiographic film (Kodak) and silver grains revealed using classical photographic techniques. HRP-containing sections were incubated for $20 \mathrm{~min}$ with $3,3^{\prime}, 5,5^{\prime}$-tetramethyl benzidine $(0.005 \%)$ in acetate buffer $(\mathrm{pH} 3.3$ $0.01 \mathrm{~m}$ ) containing sodium nitroprusside $(0.1 \%)$ and $\mathrm{H}_{2} \mathrm{O}_{2}(0.03 \%)$.

\section{Results}

In the first few experiments, we observed that blood vessels were present when the human fetuses were obtained and that a vascular network was already richly developed (Fig. 1). The vasculature formed branched vessels (stained for histochemistry of alkaline phosphatase as well as for immunocytochemistry for HLA-1, laminin, and GGT) that arborized in the fetal tissue, with the exception of the periventricular areas that contain the germinative zones.

Transplants were identified in Nissl-stained sections on the basis of cytological and cytoarchitectural features. Neural transplants formed a distinctive structure in which all transplanted neurons were grouped and segregated from host neurons. This structure was easily identified because the neurons were more densely packed than in the surrounding host tissue and transplanted neurons lacked the regular polarity corresponding to the cytoarchitectural organization of the host nuclei. The host-graft borders were therefore easily defined in Nissl-stained sections.

Surviving transplants were recovered, on the basis of their content of well-stained neurons using cresyl violet or toluidine blue (Fig. $2 A$ ). The graft did not contain accumulation of either small darkly stained cells (which could have revealed a lymphocytic or glial recruitment) or macrophages loaded with debris. Necrotic areas were not observed in the 23 transplants considered as surviving. Further analysis of the anatomy and function of blood vesscls was only undertaken in the surviving transplants. Human transplants into the rat brain varied widely in size, with diameters ranging from $500 \mu \mathrm{m}$ (e.g., Figs. $2 B, 4 a$ ) to $5 \mathrm{~mm}$ (e.g., Fig. $5 B, E$ ). The actual cause of this variability in size was not well identified. Altogether, 1-month-old transplants tended to be smaller than older ones, suggesting growth and development.

Anatomical data. At all stages, the two markers of differentiated endothelial cells used in this study (i.e., alkaline phosphatase histochemistry and GGT immunocytochemistry) labeled the vascular network in the host. A regular network containing thin blood vessels with regular caliber was visualized in the intact host nervous tissue. In the area of neuronal loss following KA injections (see, e.g., Fig. $2 B$ ) the density of blood 


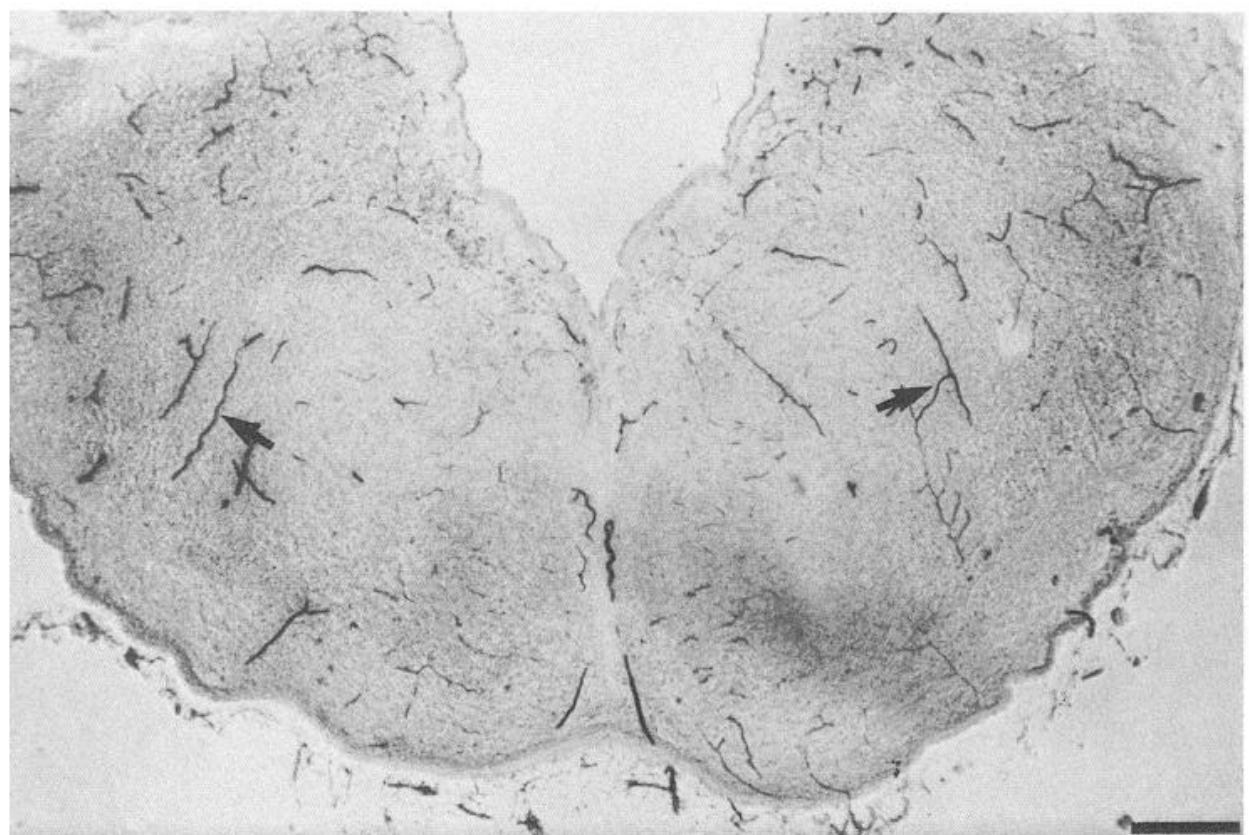

Figure 1. Blood vessels in a human 8-week-old fetal brainstem histochemically stained for alkaline phosphatase. Note the presence of numerous blood vessels (arrows). Scale bar, $200 \mu \mathrm{m}$. vessels was increased as previously described (Dusart et al., 1989). The transplants were inserted into this region. In contrast, laminin immunohistochemistry, which is mostly associated with capillaries during angiogenesis (Shigematsu et al., 1989), failed to label blood vessels in the host brain. Similarly, immunocytochemistry using the human species-specific HLA-1 antibodies and histochemistry using the lectin RCA-1 did not stain the host brain.

Results obtained in the transplants differed according to the survival time following grafting. In the 1-month-old transplants, no blood vessels were observed with the markers tested (alkaline phosphatase, HLA-1 and RCA-1) (Figs. $2 B, 4 a$ ).

Two months after transplantation, blood vessels with smallto medium-sized calibers were observed (Figs. $2 C, 3 A, B 4 b$ ). Alkaline phosphatase histochemistry and GGT immunocytochemistry gave similar results. The density of blood vessels was much reduced in the transplant as compared to the host. The border between the two tissues, defined on the basis of Nissl staining, was also clearly delineated in sections stained to reveal endothelial cells by an abrupt change in the density of blood vessels (Figs. $2 C, 4 b$ ). The density of blood vessels in the transplant itself was quite irregular. Although generally poor, the vascular network was apparently vacant in regions up to 300 $\mu \mathrm{m}$ in diameter (Fig. $4 b$ ). Laminin immunocytochemistry stained a large number of blood vessels in the transplants (Fig. 3A). Immunostained elements displayed two types of morphology. First, laminin antibodies stained cells forming blood vessels comparable to those visualized using GGT or alkaline phosphatase. Second, very thin extensions were immunostained, which seemed to arise from the walls of the formed vessels. The anti-HLA-1 antibodies-which specifically identified cells of donor origin-stained small portions of the blood vessels (Fig. $3 B)$. Similar results were obtained with the RCA-1 lectin.

At 3 months, the blood vessels stained with alkaline phosphatase or GGT were more regularly spaced within the transplants (Figs. 2D, $4 c$ ) and large areas devoid of blood vessels were not seen (Fig. $4 c$ ). The density of blood vessels was, however, still much lower than in the adult host brain. Even at this stage, the density of blood vessels was also lower than in the 8 -week-old tissue before transplantation (Fig. 1). Blood vessels within the transplants were very strongly immunoreactive for laminin and the two morphological types of stained profiles were observed. The anti-HLA-1 antibodies stained portions of blood vessels as in the 2-month-old transplants. Electron microscopic analysis revealed endothelial cells forming blood vessels displaying a mature morphology (Fig. 5C). Endothelial cells were thin and regular, formed tight junctions and contained only few pinocytic vesicles. They were surrounded by a basal lamina of regular width that separated them in most instances from very thin though regular glial processes. This mature aspect contrasted strongly with the very immature appearance of the surrounding neural tissue characterized, in particular, by the presence of large empty spaces, large neurites sometimes containing a wealth of polyribosomes and few, if any, synaptic contacts.

\section{Functional analysis}

The results obtained using various anatomical markers of the capillary wall-forming elements clearly indicated that a regular vascular network was absent from human transplants for several weeks and appeared slowly during the following months. Functional correlates of these results were analyzed using three different approaches (1) to reveal the existence of circulation in the newly formed blood vesseIs (HRP circulation) and at the same time to test for the presence of a functional blood-brain barrier, (2) to analyze the ability of a graft to take up a small compound from the blood (2-DG), and (3) to provide an index of the general metabolic status of the cells in the transplant (cytochrome oxidase).

Two rats bearing a 2- and a 3-month-old transplant received intravenous injections of horseradish peroxidase (HRP). Following circulation of HRP, the lumen of the blood vessels was well stained in the host tissue. As described previously (Dusart et al., 1989), HRP was additionally present in the parenchyma in the region of neuronal loss, indicating a leakage of the bloodbrain barrier. In the transplants, only the lumen of the blood vessels was filled with HRP reaction product (Fig. $5 E$ ), as in 

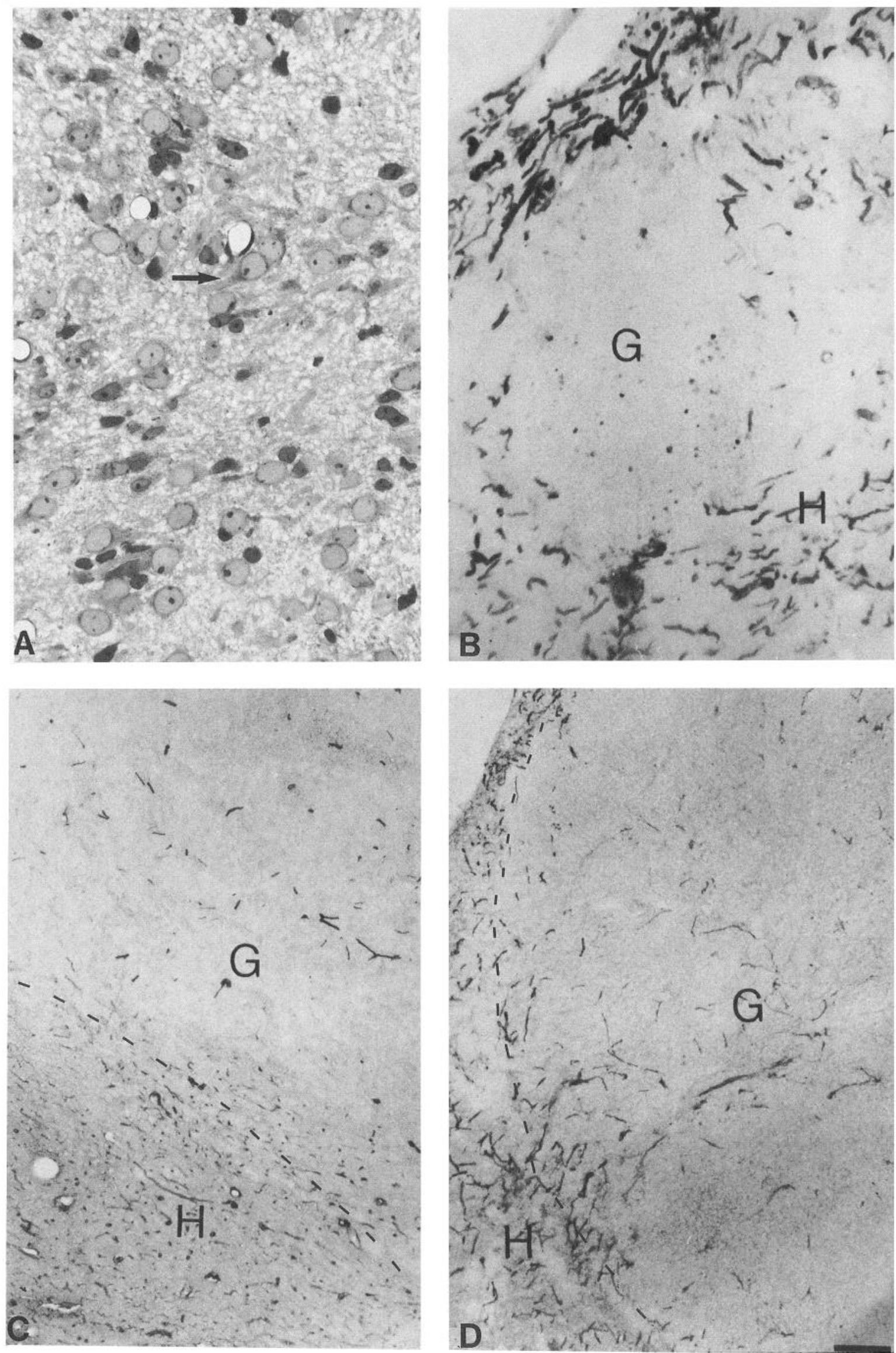

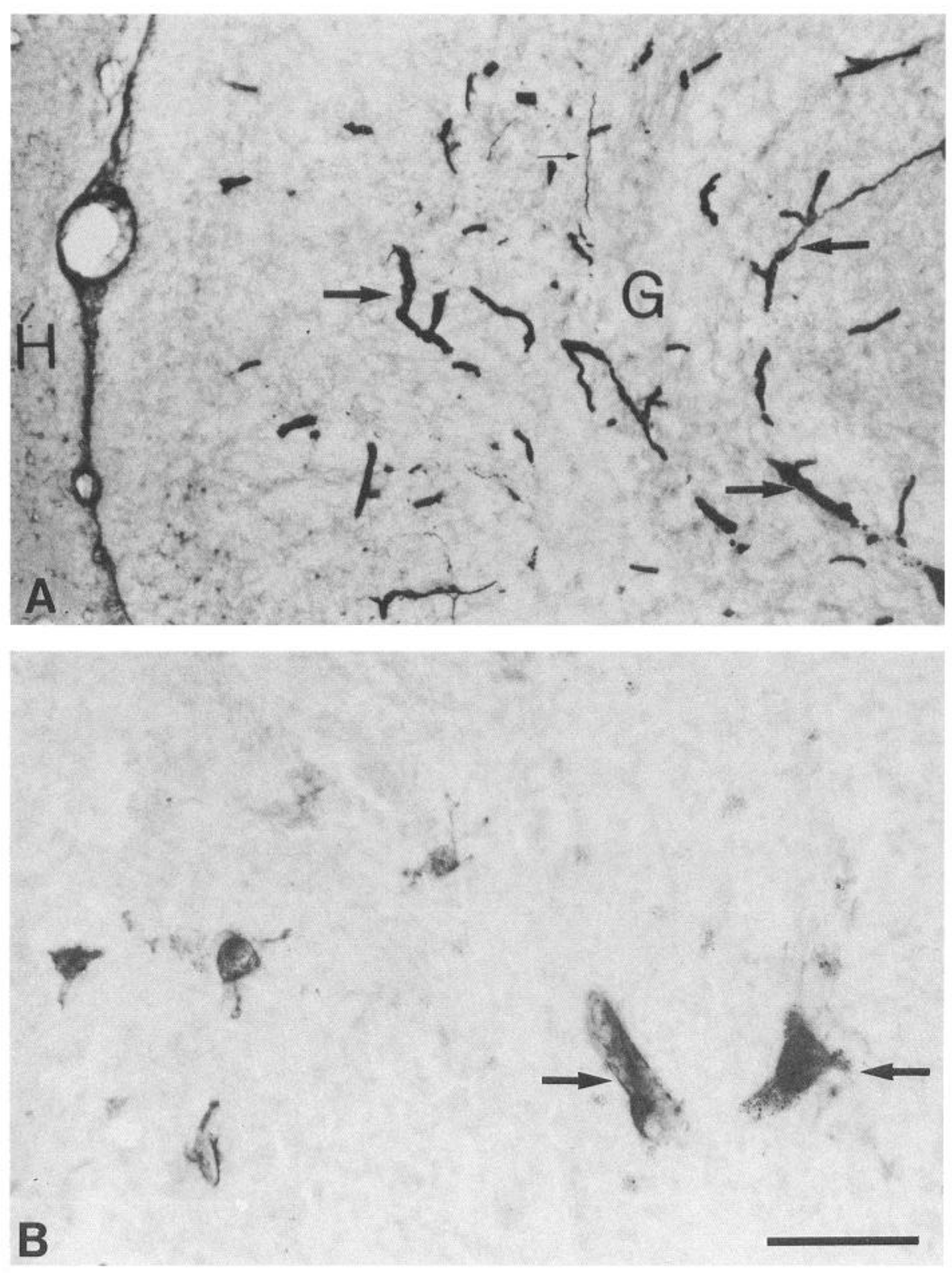

Figure 3. Characteristics of angiogenesis in 2-month-old transplants. $A$, Immunocytochemical staining using anti-laminin antibodies showing large (large arrows) and thin (thin arrow) blood vessels in a human-to-rat xenograft $(G)$ while the host tissue $(H)$ is devoid of labeling. $B$, Histochemical staining of human cells using the antiHLA-1 antibodies. Small portions of the capillaries (arrows) are stained, demonstrating the presence of endothelial cells of human origin. Unidentified isolated cells that may be human microglia are also stained. Scale bar: $200 \mu \mathrm{m}$ for $A, 75 \mu \mathrm{m}$ for $B$. the intact host tissue, revealing blood circulation and no leakage of the blood-brain barrier.

Glucose consumption was studied in two rats with 2- and 3-month-old transplants using the $14 \mathrm{C}$-deoxyglucose technique. In both cases, glucose consumption was quite apparent in the host brain (Fig. 5D). In contrast, the entire transplants appeared as unlabeled spots. Grafted cells therefore did not take up a significant amount of glucose from the blood, even though alkaline phosphatase histochemistry in adjacent sections in the two rats revealed the presence of a few blood vessels in the transplants.

Cytochrome oxidase activity was histochemically tested in 10 rats with 1-, 2-, and 3-month-old transplants. The host tissue was very well stained, demonstrating a normal metabolic activity. In contrast, the entire transplants appeared, at all stages of development, as white spots (Fig. $5 \mathrm{~A}$ ). Analysis of the cellular content of the transplants did not reveal conclusive staining except in the oldest ( 3 months) grafts. In these cases, a few cells

Figure 2. Human-to-rat xenografts $1(B), 2(C)$, and 3 months $(A, D)$ after transplantation. $A$, Toluidine blue-stained semithin section showing a 3-month-old human xenograft. Neurons are in most cases rounded cells containing a large nucleus with two or even three nucleoli and very little cytoplasm. In a few cells, one large neurite can be observed (arrow). In this field, note the presence of three blood vessels and glial cells, which are more darkly stained than neurons. $B$, Histochemical staining for alkaline phosphatase of blood vessels in the area of a small 1 -month-old human xenograft. Note the almost complete lack of blood vessels in the transplant $(G)$ while the host $(H)$ is well vascularized. $C$, Histochemical staining with alkaline phosphatase of a 2-month-old human xenograft $(G)$. A few blood vessels are present in the transplant at this stage. $D$, Immunocytochemical staining using $\gamma$-glutamyl-transpeptidase antibodies showing endothelial cells in a 3-month-old graft $(G)$. Blood vessels are still much less numerous in the transplant than in the host tissue $(H)$. Scale bars: $A, 35 \mu \mathrm{m} ; B, 100 \mu \mathrm{m} ; C$ and $D, 250 \mu \mathrm{m}$. 


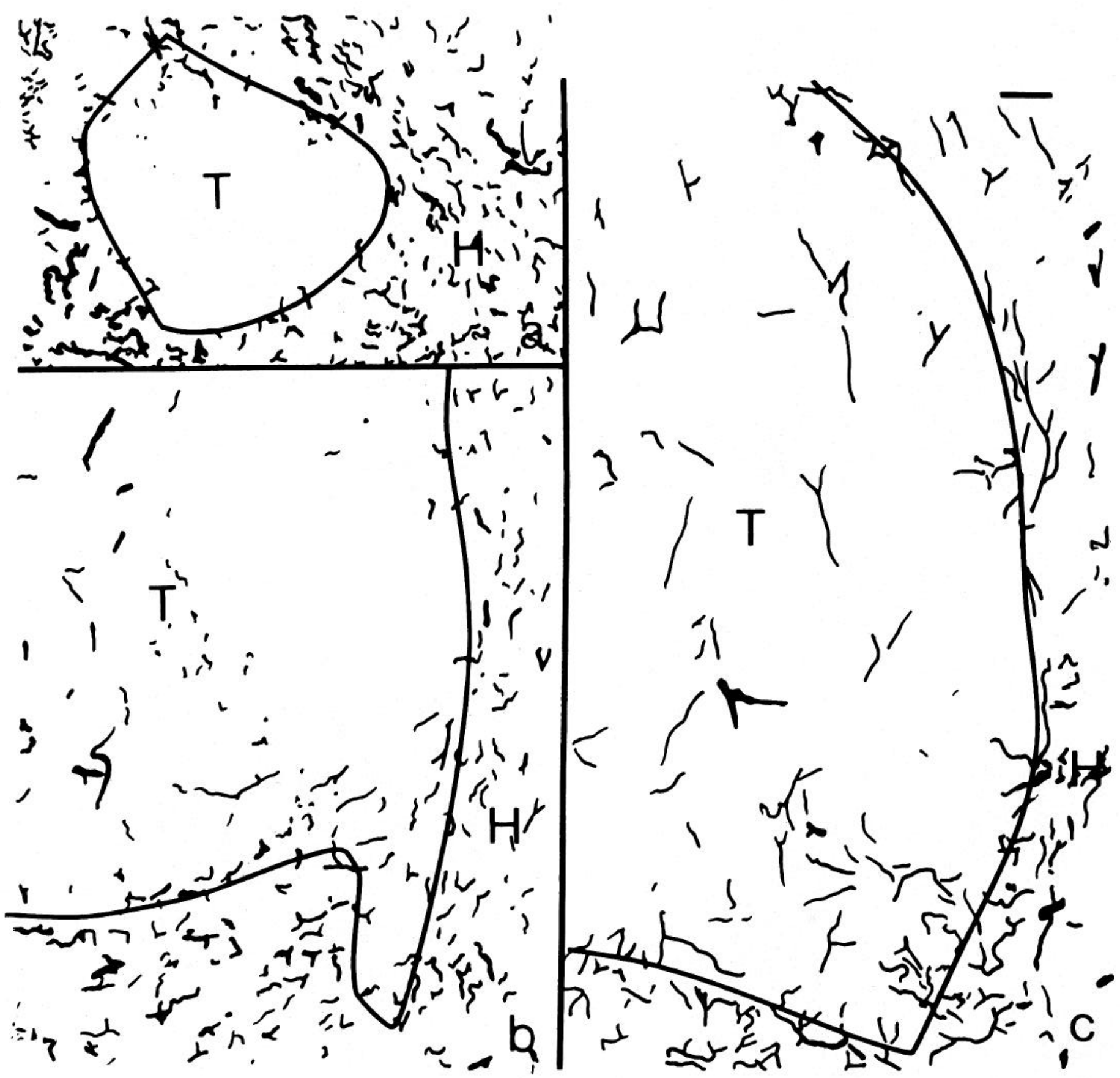

Figure 4. Camera lucida drawings showing the vascular network in 1- $(a), 2-(b)$, and 3- $(c)$ month-old transplants. $T$, transplant; $H$, host. The 1 -month-old transplant is also illustrated in Figure $2 B$. Note the absence of blood vessels at 1 month and in a large portion at 2 months. Scale bar (in $c$ ), $100 \mu \mathrm{m}$.

Figure 5. Fine structure and functional characteristics of human xenografts to the rat brain. $A$ and $B$, Histochemical staining of cytochrome oxidase activity in a 2-month-old human-to-rat xenograft $(G)$. Note, in $A$, that the large transplant appears as a white spot within the well-stained host brain $(H)$. In $B$, two neurons exhibit somatodendritic staining. $C$, Electron photomicrograph showing an endothelial cell forming a blood vessel in a 3-month-old transplant. Note the mature morphology of the capillary wall. This contrasts with the immaturity of the surrounding tissue characterized by large intercellular spaces and the lack of synapses. $D$, Autoradiograph showing ${ }^{14} \mathrm{C}-2$-DG uptake in a 3-month-old human-to-rat xenograft. The graft $(G)$ appears as a white spot in the well-labeled host brain $(H)$. $D$, Peroxidase histochemistry in a relatively well-vascularized portion of a 2-month-old human-to-rat transplant, using TMB, after horseradish peroxidase (HRP) circulation in the blood. HRP reaction product decorates the blood vessels walls demonstrating the existence of blood flow. Scale bar: $500 \mu \mathrm{m}$ for $A$ and $E ; 8 \mu \mathrm{m}$ for $B ; 3 \mu \mathrm{m}$ for $C ; 400 \mu \mathrm{m}$ for $D$. 

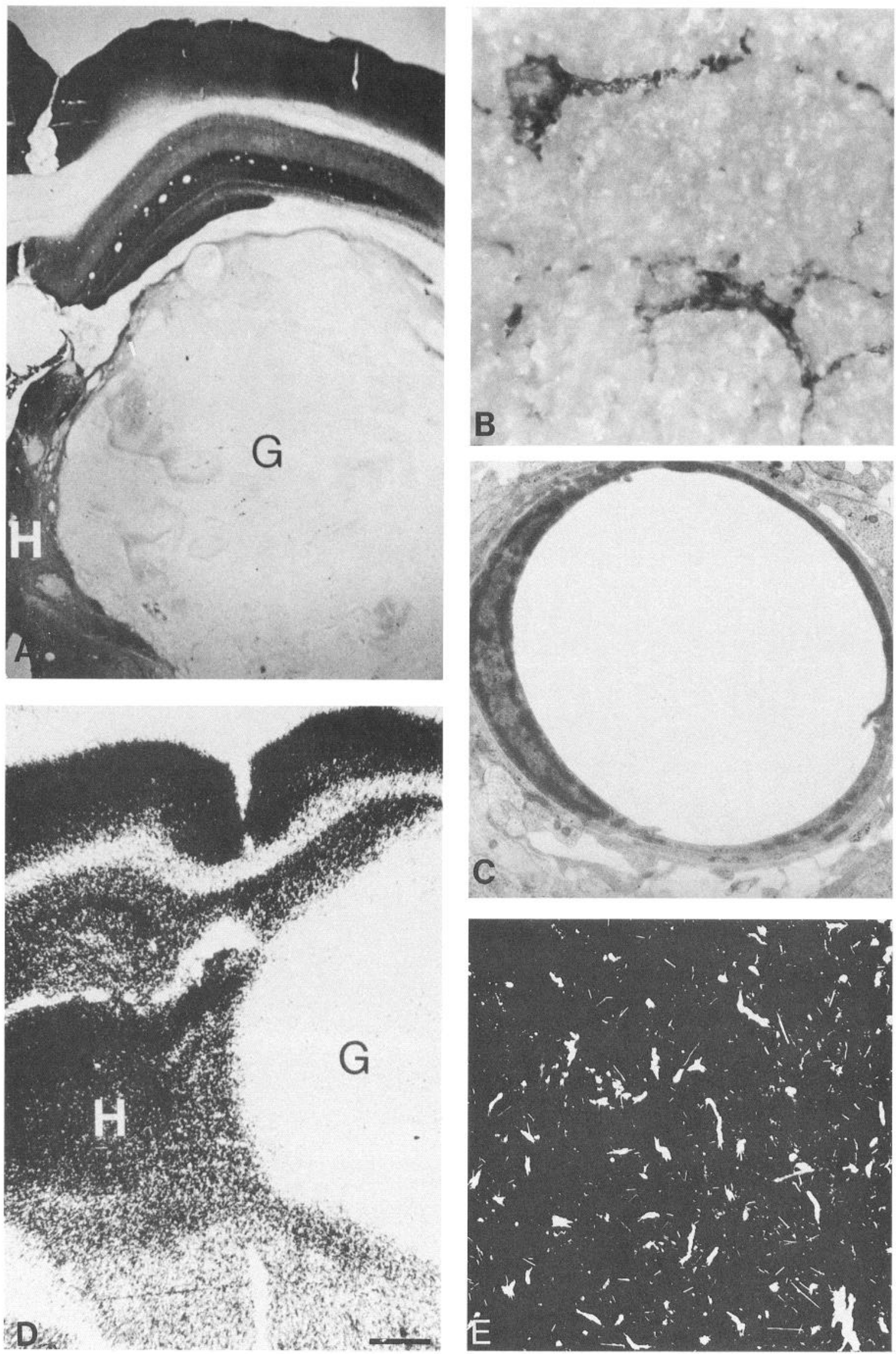
identified as neurons on a morphological basis displayed cytochrome oxidase activity localized to the cell body and dendrites (Fig. 5B).

\section{Discussion}

This study examines the development of the vascular network in human neural xenografts to the adult rat brain. We demonstrate the existence of a long-term delay before the establishment of a vascular network in this tissue. The existence of a welldeveloped network of brain vessels in the fetal primordium used for transplantation indicates that this phenomenon is at least partly related to a dedifferentiation of the donor endothelial cells. The functional significance of these results regarding the maturation of transplanted neurons probably requires further investigation for the prospect of clinical applications of human transplants.

\section{Transitory dedifferentiation of donor endothelial cells}

Using various markers of differentiation (see discussion in Dermietzel and Krause, 1991) endothelial cells forming blood vessels were observed in the region of the CNS of human fetuses used for xenografting in our experiments. This implies that differentiated endothelial cells were transplanted into the rat brain. The same markers failed, however, to reveal endothelial cells in the 1 month grafts of this study. One hypothesis for their disappearance is that donor endothelial cells are eliminated after transplantation. Cells of host origin later enter the transplant and form blood vessels independently. This does not seem to be the case, however, since a few endothelial cells of human origin were stained with human specific markers (anti-HLA 1 antibodies) in the capillary walls of 2- and 3-month-old transplants.

Reappearance of human endothelial cells in the 2- and 3 -month-old grafts strongly suggests that they were substained at an immature stage rather than eliminated. In that sense, our results compare with those obtained by Broadwell et al. (1987, 1991) and Dusart et al. (1989), who demonstrated that blood circulation occurs after a delay of more than a week in allo- and xenografts in rodents, even though endothelial cells are present at earlier stages (Lawrence et al., 1984; Krum and Rosenstein, 1988; Krum et al., 1991; Mrejen et al., 1992). The main difference between the present results and those quoted above is the length of the delay before vascularization, which in the humanto-rat xenografts of this study amounted to more than a month. This delayed angiogenesis also implies that host endothelial cells do not form blood vessels rapidly in the graft. Using various markers, a number of researchers have demonstrated that capillary walls in transplants derive from endothelial cells of both donor and host origin (Lindsay and Raisman, 1984; Krum and Rosenstein, 1988; Nakano et al., 1989; Sloan et al., 1990; Mrejen et al., 1992). The fast migration of host cells into rodent transplants is most probably related to the presence of angiogenic factors. Conversely, the absence of an efficient migration from host endothelial cells into the human transplants during the first month may therefore relate to the lack of such factors. Endothelial cells are a major source of angiogenic factors acting in an autocrine fashion (Maione and Sharp, 1990). It is tempting to speculate that synthesis of these angiogenic factors is associated with a specific stage of differentiation, which is not reached for a long period of time after transplantation of human tissue. It should be noted, however, that microglial cells are also potent sources of angiogenic factors (Polverini et al., 1977; Klagsbrun and D'Amore, 1991; Sunderkötter et al., 1991) and that host microglia enter the human to rat xenografts within weeks, in the absence of necrosis or rejection (C. Geny, S. Naimi-Sadaoui, A. M. Belkadi, R. Jeny, and M. Peschanski, unpublished observations).

\section{Dependence of the rate of angiogenesis upon the species of the donor}

Comparison of the rate of angiogenesis in the rat-to-rat and human-to-rat transplants indicates a striking difference both in the duration of the delay and the rate of the establishment of a vascular network. Perfusion could be observed in rat allografts between 8 and $20 \mathrm{~d}$ after transplantation (Broadwell et al., 1987, 1991; Dusart et al., 1989) and a normal density of vessels was reached before the second month (Dusart et al., 1989). In contrast, no blood vessels were observed in human-to-rat xenografts at 1 month and the vascular network was still poor at 3 months. Two potential causes for this difference were studied, and excluded, in companion experiments. The first demonstrated that host microglial cells were present in the 1-month-old human transplant, thus precluding a potential barrier for cell migration between host and donor tissues (Geny, Naimi-Sadaoui, Belkadi, Jeny, and Peschanski, unpublished observations). The second showed that cyclosporin A did not modify the rate of angiogenesis in rat allografts (Geny and Peschanski, unpublished observations) although it reduces the rate of proliferation of endothelial cells in vitro (Sharpe et al., 1989; Ferns et al., 1990).

The difference in the rate of angiogenesis seems to parallel differential rates of maturation of the rat versus the human neural tissue. Two months after the stage at which the fetal tissue was taken for transplantation (embryonic day 15 in the rat, gestational week 6-8 in the human) rats are adults while humans are still in utero. Previous results obtained with specific neuronal populations have also emphasized differential rates of maturation between species (Brundin et al., 1986; Strömberg et al., 1986).

The precise mechanisms by which the rates of maturation act on those of angiogenesis in transplants remain unknown. A direct dependence of angiogenesis on a specific stage of maturation of the transplanted tissue is not likely. A well-developed vascular network existed in the fetal piece taken for transplantation and, at least in the rat, no major retardation in neuronal maturation is introduced by the transplantation process (Nothias et al., 1989; Cadusseau et al., 1994). The genetic disparity between host and donor species could be also questioned. Angiogenesis is a complex phenomenon resulting from multiple interactions between endothelial cells, angiogenic factors, and extracellular matrices. Signaling mechanisms for angiogenesis may be species specific but evidence supporting this hypothesis is lacking. For instance, acidic FGF, which is the principal angiogenic factor in the brain, is highly conserved among vertebrates (Risau et al.,1988). Otherwise, in other models of xenografts, angiogenesis occurs clearly within $10 \mathrm{~d}$ (mouse to rat, Nakano et al., 1989; Mrejen et al., 1992; rabbit to mouse, Mrejen et al., 1992).

In the absence of a convincing hypothesis, it is templing to speculate and to consider the issue from a different point of view. In the transplantation process, fetal neural tissue is abruptly faced with an adult environment. In particular, adult blood is quite different from fetal blood, which is normally filtered by the placenta (Takehara et al., 1990), and possesses specific biochemical features including low partial pressure of oxygen and 
other gases (Edelstone et al., 1989; Nikolaides et al., 1989). The weak oxidative metabolism of the human transplants and the low levels of glucose uptake at early stages after grafting in both rat (Juliano et al., 1988) and the human transplants indicate that neural cells can survive and develop in the absence of a blood supply of oxygen and glucose. Conversely, a large concentration of oxygen might be detrimental for fetal tissue because enzymes necessary for detoxification of oxygen radicals, such as catalase, are not synthesized at an early stage of gestation (Mavelli et al., 1982; Houdou et al., 1991). Partial detoxification of the maternal blood by the placenta has been reported (Takehara et al., 1990). In the absence of the placental filter, a high concentration of oxygen in the blood may provide a trigger for other protective systems, present in immature cells, the outcome of which includes the maintenance of endothelial cells in an undifferentiated state.

In conclusion, the main result of this study is the observation that human neural transplants in the adult brain survive for weeks, if not months, in the absence of a normal blood supply. This result bears clinical significance since similar transplants are already implanted in human patients. This finding suggests, for instance, that visualization of the graft using blood-borne tracers (e.g., ${ }^{18}$ F-dopa, Sawle et al., 1992) may not be relevant for at least a few months. Concerns had also been raised by in vitro experiments indicating that chronic $\mathrm{L}$-dopa intake may have detrimental effects on early development of transplanted nigral neurons in patients with Parkinson's disease (Steece-Collier et al., 1991). This seems unlikely to happen if early-developing neurons are essentially not vascularized.

\section{References}

Björklund A, Lindvall O, Isacson O, Brundin P, Wictorin K, Strecker RE, Clarke DJ, Dunnett SB (1987) Mechanisms of action of intracerebral neural implants: studies on nigral and striatal grafts to the lesioned striatum. Trends Neurosci 10:509-516.

Broadwell RD, Charlton HM, Balin BJ, Salcman M (1987) Angioarchitecture of the CNS pituitary gland and intracerebral grafts revealcd with peroxidase cytochemistry. J Comp Neurol 260:47-62

Broadwell RD, Charlton HM, Ebert P, Hickey WF, Shirazi Y, Villegas JC, Wolff AL (1990) Angiogenesis and the blood-brain barrier in solid and dissociated cell grafts within the CNS. Prog Brain Res 82: 95-101

Broadwell RD, Charlton HM, Ebert PS, Hickey WF, Shirazi Y, Villegas J, Wolff AL (1991) Allografts of CNS tissue and cell suspension grafts. Exp Neurol 112:1-28

Brundin P, Nilsson OG, Strecker RE, Lindvall O, Astedt B, Björklund A (1986) Behavioural effects of human fetal dopamine neurons grafted in a rat model of Parkinson's disease. Exp Brain Res 65:235240

Brundin P, Strecker RE, Widner H, Clarke DJ, Nilsson OG, Astedt B, Lindvall $O$, Björklund $\Lambda$ (1988) Human fetal dopamine neurons grafted in a rat model of Parkinson's disease: immunological aspects, spontaneous and drug-induced behaviour, and dopamine release. Exp Brain Res 70:192-208.

Cadusseau J, Rapisardi S, Peschanski M (1994) Morphological maturation of thalamic neurons as studied in fetal neural transplants. $J$ Comp Neurol, in press.

Dermietzel R, Krause D (1991) Molecular anatomy of the blood-brain barrier as defined by immunocytochemistry. Int Rev Cytol 127:57108.

Dusart I, Nothias F, Roudier F, Besson JM, Peschanski M (1989) Vascularization of fetal cell suspension grafts in the excitotoxically lesioned adult rat thalamus. Dev Brain Res 48:215-228.

Edelstone DI, Darby MJ, Bass K, Miller K (1989) Effects of reductions in hemoglobin-oxygen affinity and hematocrit level on oxygen consumption and acid-base state in fetal lambs. Am $\mathbf{J}$ Obstet Gynecol 160:215-228.
Ferns G, Reidy M, Ross R (1990) Vascular effects of ciclosporine A in vivo and in vitro. Am J Pathol 137:403-413

Freed CR, Breeze RE, Rosenberg NL, Schneck SA, Kriek E, Qi JX, Lone T, Zhang YB, Snyder JA, Wells TH, Olson Ramig L, Thompson L, Mazziota JC, Huang SC, Grafton ST, Brooks D, Sawle G, Schroter G, Ansari AA (1992) Survival of implanted fetal dopamine cells and neurologic improvement 12 to 46 months after transplantation for Parkinson's disease. N Engl J Med 327:1549-1555.

Freed WJ (1991) Substantia nigra grafts and Parkinson's disease: from animal experiments to human therapeutic trials. Restor Neurol Neurosci 3:109-134

Houdou S, Kuruta H, Hasegawa M, Konomi H, Takashima S, Suzuki Y, Hashimoto T (1991) Developmental immunohistochemistry of catalase in the human brain. Brain Res 556:267-270.

Jeny R, Peschanski M, Cynober E, Kammoun M, Bouzaghar A, Hammani M, Cesaro $P$ (1993) Apport de l'échographie dans les prélèvements embryonnaires à visèe de greffes intracérébrales dans le traitement de la maladie de Parkinson. J Echo Med Ultras 14:19-22.

Juliano S, Dusart I, Peschanski M (1988) Somatic activation of thalamic neurons transplanted into lesioned somatosensory thalamus. Brain Res 478:356-360.

Klagsbrun M, D'Amore PA (1991) Regulators of angiogenesis. Annu Rev Physiol 53:217-239.

Krum JM, Rosenstein JM (1988) Pattern of angiogenesis in neural transplant models. II. Fetal neocortical transplants. J Comp Neurol 271:331-345.

Krum JM, More NS, Rosenstein JM (1991) Brain angiogenesis: variations in vascular basement membrane glycoprotein reactivity. Exp Neurol 111:152-165.

Lawrence JM, Huang SK, Raisman G (1984) Vascular and astrocytic reactions during establishment of hippocampal transplants in adult host brain. Neuroscience 12:745-760.

Lindsay RM, Raisman G (1984) An autoradiographic study of neuronal development vascularization and glial cell migration from hippocampal transplants labelled in intermediate explant culture. Neuroscience 12:513-530.

Lindvall $\mathrm{O}$, Brundin $\mathrm{P}$, Widner $\mathrm{H}$, Rehncrona $\mathrm{S}$, Gustavii B, Frackowiak, Leenders KL, Sawle G, Rothwell JC, Marsden CD, Björklund A (1990) Grafts of fetal dopamine neurons survive and improve motor function in Parkinson's disease. Science 247:574-577.

Maione TE, Sharp RJ (1990) Development of angiogenesis inhibitors for clinical applications. Trends Pharmacol 11:457-461.

Mavelli I, Rigo A, Federico R, Ciriolo MR, Rotilio G (1982) Superoxide dismutase glutathione peroxidase and catalase in developing rat brain. Biochem J 204:535-540.

Mrejen S, Quinonero J, Moinard F, Ghandour S, Jacque C (1992) Xenogenic transplantation into newborn rodent brain: neovascularization of the graft by the host. Dev Neurosci 14:144-152.

Nakano Y, Takei K, Toya S, Tsukada Y, Gandhour S, Kohsaka S (1989) Mosaic reconstruction of blood vessels in mouse neocortical tissue transplanted into the third ventricle of rat brain. Brain Res 496:336340.

Nikolaides KH, Economides DL, Soothill PW (1989) Blood gases pH and lactate in appropriatc- and small-for-gestational-age fetuses. Am J Obstet Gynecol 161:996-1000.

Nothias F, Dusart I, Roudier F, Peschanski M (1989) First month of development of fetal neurons transplanted as a cell suspension into the adult CNS. Neuroscience 33:607-616.

Peschanski M, Isacson O (1988) Fetal homotypic transplant in the excitotoxically neuron depleted thalamus: light microscopy. J Comp Neurol 274:449-463.

Peschanski M, Defer G, N'Guyen JP, Ricolfi F, Monfort JC, Remy P, Geny C, Samson Y, Hantraye P, Jeny R, Gaston A, Kéravel Y, Degos $J D$, Cesaro $P$ (in press) Bilateral motor improvement and alteration of L-dopa cffect in two patients with Parkinson's disease following intrastriatal transplantation of fetal ventral mesencephalon. Brain, in press.

Polverini PJ, Cotran RS, Gimbrone MA, Unanue ZE (1977) Activated macrophages induce vascular proliferation. Nature 269:804-806.

Risau W, Gautschi-sova P, Böhlen (1988) Endothelial cell growth factors in embryonic and adult chick brain are related to human acidic fibroblast growth factor. EMBO 7:959-962.

Robertson PL, Dubois M, Bowman PD, Goldstein GW (1985) Angiogenesis in developing rat brain: an in vivo and in vitro study. Dev Brain Res 23:219-223. 
Rosenstein JM (1987) Neocortical transplants in the mammalian brain lack a blood-brain barrier to macromolecules. Science 235:772-773.

Sawle GV, Bloomfield PM, Björklund A, Brooks DJ, Brundin P, Leenders KL, Lindvall O, Marsden CD, Rehncrona S, Widner H (1992) Transplantation of fetal dopamine neurons in Parkinson's disease: PET [ $\left.{ }^{18} \mathrm{~F}\right]-6$-L-fluorodopa studies in two patients with putaminal implants. Ann Neurol 31:166-173.

Sharpe RJ, Arndt KA, Bauer SI, Maione TE (1989) Ciclosporine inhibits basic fibroblast growth factor-driven proliferation of human endothelial cells and keratinocytes. Arch Dermatol 125:1359-1362.

Shigematsu K, Kamo H, Akiguchi I, Kameyama M, Kimura H (1989) Neovascularization of transplanted central nervous tissue suspensions: an immunohistochemical study with laminin. Neurosci Lett 99:18-23.

Sloan DJ, Baker BJ, Puklavec M, Charlton HM (1990) The effect of site transplantation and histocompatibility differences on the survival of neural tissue transplanted to the CNS of defined inbred rat strains. Prog Brain Kes 82:141-152.

Spencer DD, Robbins RJ, Naftolin F, Marek KL, Vollmer T, Leranth C, Roth RH, Price LH, Gjedde A, Bunney BS, Sass KJ, Elsworth JD Leon Kier E, Makuch R, Hoffer PB, Redmond DE (1992) Unilateral transplantation of human fetal mesencephalic tissue into the caudate nucleus of patients with Parkinson's disease. N Engl J Med 327:15411548 .
Steece-Collier K, Yurek DM, Collier TJ, Sladek JR (1991) Neuropharmacological interactions of levodopa and dopamine grafts: possible impaired development and function of grafted embryonic neurons. In: Kestorative neurology, Vol 4, Intracerebral transplantation in movement disorders (Lindvall $\mathrm{O}$, Björklund $\mathrm{A}$, Widner $\mathrm{H}$, eds), pp 325-331. Amsterdam: Elsevier.

Strömberg I, Bygdeman M, Goldstein M, Seiger A, Olson L (1986) Human fetal substantia nigra grafted to the dopamine denervated striatum of immunosuppressed rats: evidence for functional reinnervation. Neurosci Lett 71:271.

Sunderkötter C, Goebeler M, Schulze-Osthoff K, Bhardwaj R, Sorg C (1991) Macrophage-derived angiogenesis factors. Pharmacol Ther 51:195-216.

Takehara Y, Yoshioka T, Sasaki J (1990) Changes in the level of lipoperoxide and antioxidant factors in human placenta during gestation. Acta Med Okayama 44:103-111.

Wictorin K, Björklund A (1992) Axon outgrowth from grafts of human embryonic spinal cord in the lesioned adult rat spinal cord. Neuroreport 3:1045-1048.

Widner H, Tetrud J, Rehncrona S, Snow B, Brundin P, Gustavii X, Björklund A, Lindvall O, Langston W (1992) Bilateral fetal mesencephalic grafting in two patients with parkinsonism induced by 1-methyl-4-phenyl-1236-tetrahydropyridine (MPTP). N Fingl J Med $327: 1556-1563$. 